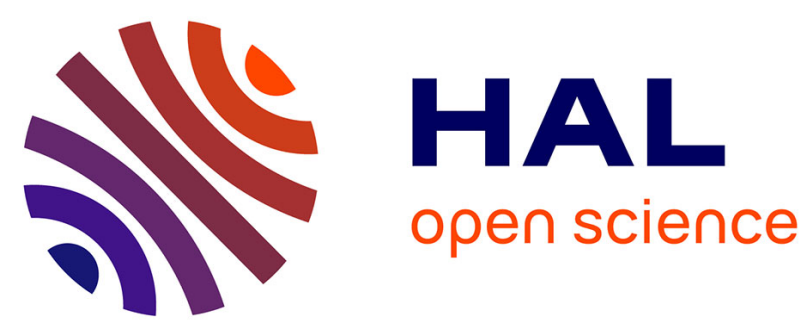

\title{
STRUCTURAL, ELECTRONIC AND MAGNETIC PROPERTIES OF THE LINEAR CHAIN COMPOUNDS CsMI3(M = V, Cr, Mn) FROM 129I MÖSSBAUER SPECTROSCOPY
}

\author{
J. Sanchez, J. Friedt, G. Jehanno
}

\section{To cite this version:}

J. Sanchez, J. Friedt, G. Jehanno. STRUCTURAL, ELECTRONIC AND MAGNETIC PROPERTIES OF THE LINEAR CHAIN COMPOUNDS CsMI3(M = V, Cr, Mn) FROM 129I MÖSSBAUER SPECTROSCOPY. International Conference on The Applications of The Mössbauer Effect 8, 1978, Kyoto, Japan. pp.C2-398-C2-399, 10.1051/jphyscol:19792138 . jpa-00218510

HAL Id: jpa-00218510 https://hal.science/jpa-00218510

Submitted on 1 Jan 1979

HAL is a multi-disciplinary open access archive for the deposit and dissemination of scientific research documents, whether they are published or not. The documents may come from teaching and research institutions in France or abroad, or from public or private research centers.
L'archive ouverte pluridisciplinaire HAL, est destinée au dépôt et à la diffusion de documents scientifiques de niveau recherche, publiés ou non, émanant des établissements d'enseignement et de recherche français ou étrangers, des laboratoires publics ou privés. 
STRUCTURAL, ELECTRONIC AND MAGNETIC PROPERTIES OF THE LINEAR CHAIN COMPOUNDS $\mathrm{CsMI}_{3}\left(M=V, C_{r}, M_{n}\right)$ FROM 129 I MÖSSBAUER SPECTROSCOPY

\author{
J.P. Sanchez, J.M. Friedt and G. Jehanno* \\ Laboratoire de Chimie Nucléaire, Centre de Recherches Nucléaires, B.P. 20, 67037 Strasbourg Cedex, \\ France. \\ "Service de Physique du Solide et de Résonance Magnétique, Centre d'Etudes Nucléaires de Saclay, \\ Orme des Merisiers, B.P. 2, 91190 Gif-sur-Yvette, France.
}

\begin{abstract}
Résumé.- L'analyse des spectres Mössbauer de ${ }^{129} \mathrm{I}$ dans les composés $\mathrm{CsMI}_{3}(\mathrm{M}=\mathrm{V}, \mathrm{Cr}, \mathrm{Mn})$ a permis de déduire la symétrie locale de $1^{\prime}$ ion de transition. Une étude complémentaire par diffraction de rayons $\mathrm{X}$ a montré que $\mathrm{CsCrI}_{3}$ présente une transition de phase cristallographique à $165 \mathrm{~K}$. Un ordre magnétique a êté mis en évidence dans $\mathrm{CsCrI}_{3}$ et $\mathrm{CsMnI}_{3}$. Les densitês de charge et de spin dans les orbitales de valence de l'iode ont été déduites à partir des paramètres d'interactions hyperfines. Un arrangement antiferromagnétique des moments le long de 1'axe des chaînes est suggéré pour CsMnI 3.

Abstract. - The coordination symetry of the $\mathrm{M}^{2+}$ ion in the compounds $\mathrm{CsMI}_{3}(\mathrm{M}=\mathrm{V}, \mathrm{Cr}, \mathrm{Mn})$ is deduced from ${ }^{129} \mathrm{I}$ Mössbauer spectroscopy. For $\mathrm{CsCrI}_{3}$, a crystal phase transition is observed at $165 \mathrm{~K}$. Magnetic transitions are observed for $\mathrm{CsCrI}_{3}$ and $\mathrm{CsMnI}_{3}$. The hyperfine interactions parameters are interpreted for the charge and spin densities in the iodine valence orbitals. An antiferromagnetic alignement of the spins along the chain axis is suggested for $\mathrm{CsMnI}_{3}$.
\end{abstract}

The compounds $\mathrm{CsMI}_{3}$ have attracted much interest in view of their linear chain structure which gives rise to predominant1y one dimensional electronic and magnetic properties.

From previous single crystal X-ray diffraction studies of $\mathrm{CsVI}_{3}$ and $\mathrm{CsMnI}_{3}$, it was concluded that the space group of these compounds is either $\mathrm{P}_{3} / \mathrm{mmc}$ or $\mathrm{P}_{3} \mathrm{mc} / 1 /$. However, for $\mathrm{CsMnI}_{3}$, a more recent work has showed that the centrosymmetric $\mathrm{P}_{3} / \mathrm{mmc}$ space group gave the best agreement with the measured intensities $/ 2 /$. For both structures, the transition metal ion is surrounded by a distorded octahedron of halide ions, However, the M-I-M bridges are symmetric for the space group $\mathrm{P}_{3} / \mathrm{mmc}$ whereas they are asymetric for the lower symmetry $\mathrm{P}_{3} \mathrm{mc}$ space group (figure 1). The ${ }^{129} \mathrm{I}$ Mössbauer measurements on powder samples reveal for both $\mathrm{CsVI}_{3}$ and $\mathrm{CsMnI}_{3}$ a single crystallographic iodine site with a positive quadrupole coupling constant (figure 2). These results allow to conclude that both compounds crystallize in the space group $\mathrm{P}_{3} / \mathrm{mmc}$.

The ${ }^{129}$ I Mössbauer spectra of $\mathrm{CsCrI}_{3}$ measured below $100 \mathrm{~K}$ reveal the existence of two non-equivalent crystallographic iodine sites with relative occupation 1 : 2 (figure 2). The $27.8 \mathrm{keV}$ Mössbauer resonance cannot be measured at higher temperatures because of the sharp decrease of the Debye-Waller factor. The occurence of two iodine sites is incom- patible with either structure proposed from X-ray diffraction study performed at $300 \mathrm{k} / 1 /$.
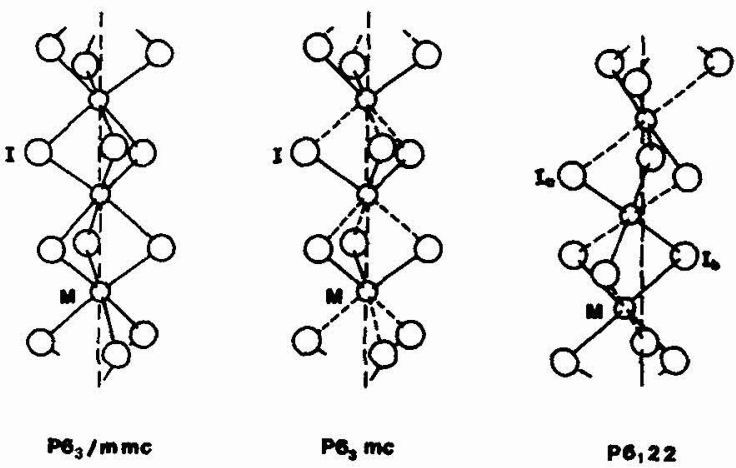

Fig. 1 : Partial view of the linear chain showing the coordination symmetry of the transition metal ion for various space group.

Indeed, our investigation of the powder X-ray diffraction of $\mathrm{CsCrI}_{3}$ as a function of temperature reveals a crystal phase transition at $165 \pm 5 \mathrm{~K}$ from a high temperature hexagonal phase $(a=8.12 \AA$ $c=6.85 \AA$ ) to a low temperature phase of lower symmetry (1ikely orthorhombic). In the low temperature phase the coordination of the $\mathrm{Cr}^{2+}$ ion is deduced from the Mössbauer results to be an axially distorted octahedron (figure 1), similar for instance to that of $\mathrm{Cu}$ in $\mathrm{CsCuCl}_{3}$ which crystallizes in the $\mathrm{P}_{1} 22$ space group. A static Jahn-Teller 
distortion may explain the crystal phase transition.

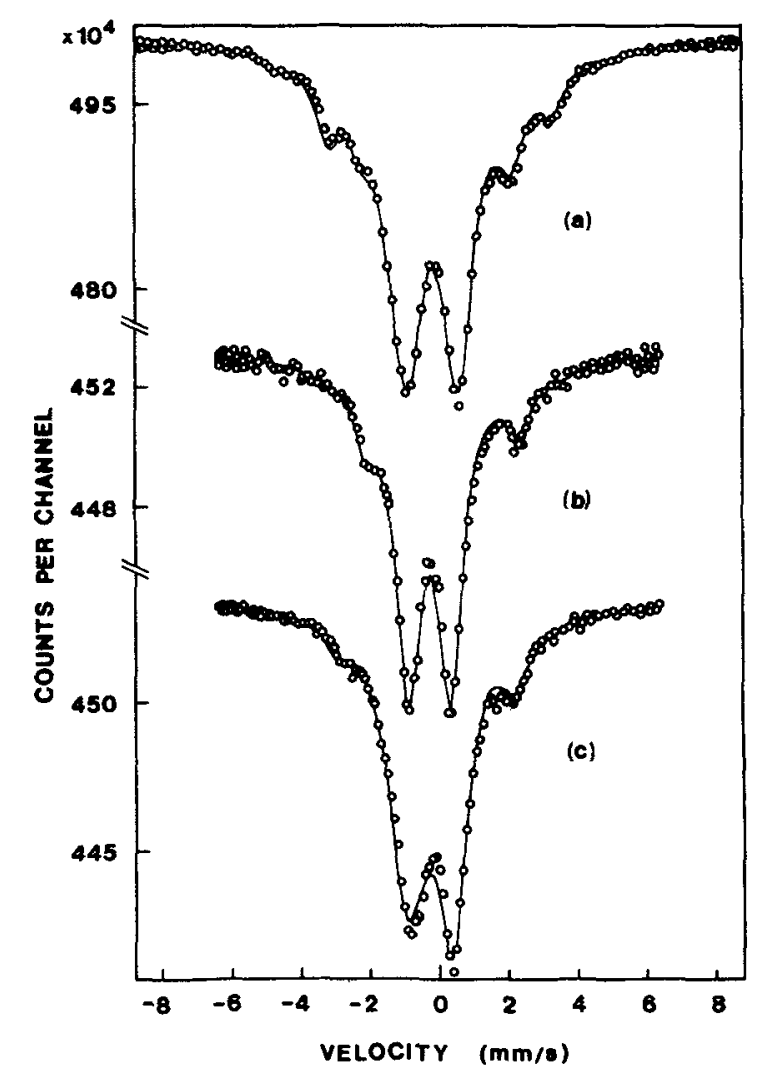

Fig. 2 : Mössbauer spectra of ${ }^{129} \mathrm{I}$ in $\mathrm{CsMI}_{3}$.

a) $\mathrm{CsCrI}_{3}$ at $77 \mathrm{~K}$

b) $\mathrm{CsMnI}_{3}$ at $21 \mathrm{~K}$

c) $\mathrm{CsMnI}_{3}$ at $1.4 \mathrm{~K}$

Magnetic ordering is observed in $\mathrm{CsCrI}_{3}$ and $\mathrm{CsMnI}_{3}$; the $3 \mathrm{~d}$-order temperatures are 18 and $10 \mathrm{~K}$ respectively. Due to the poor spectral resolution connected with the low symmetry of the $\mathrm{Cr}^{2+}$ ion, the analysis of the magnetic data in $\mathrm{CsCrI}_{3}$ is uncertain. In $\mathrm{CsMnI}_{3}$, the interpretation of the transferred hyperfine field at the ${ }^{129}$ I nucleus indicates an antiferromagnetic spin arrangement within the chains, with the magnetic moments of the $\mathrm{Mn}^{2+}$ ions directed parallel to the chain axis.

The charge densities in the valence orbitals of iodine are obtained from the analysis of the isomer shift and quadrupole interaction parameters. The spin densities are evaluated from the transferred magnetic hyperfine interaction $/ 3 /$. Quantitative estimates for the bonding coefficients and details of the electronic and magnetic exchange mechanisms are drawn from these data (Table I).
Table I

\begin{tabular}{|ll|c|c|c|c|c|}
\hline Compound & $\mathrm{N}_{\mathrm{s}}$ & $\mathrm{N}_{\mathrm{p} z}$ & $\mathrm{~N}_{\mathrm{p} x}$ & $\mathrm{~N}_{\mathrm{py}}$ & $\mathrm{f}_{\sigma^{-\mathrm{f}_{\mathrm{T}}}}$ \\
\hline $\operatorname{csvI}_{3}$ & 1.99 & $2^{*}$ & 1.84 & 1.90 & - \\
$\operatorname{cscrI}_{3}$ & $\mathrm{a}-$ site & 1.99 & 1.81 & 1.93 & $2^{*}$ & - \\
$\operatorname{csMrI}_{3}$ & & 1.99 & $2^{*}$ & 1.80 & 1.84 & - \\
& & 2 & $2^{*}$ & 1.84 & 1.90 & $1.5 \times 10^{-2}$ \\
\hline
\end{tabular}

*assumed value.

Charge and spin densities at ${ }^{129} \mathrm{I}$ in $\mathrm{CsMI}_{3}$ $(\mathrm{M}=\mathrm{V}, \mathrm{Cr}, \mathrm{Mn}) . \mathrm{N}_{\mathrm{s}}$ and $\mathrm{N}_{\mathrm{pi}}$ represent the charge densities in the $5 \mathrm{~s}$ and $5 \mathrm{pi}$ valence orbitals of iodine. $f_{\sigma}$ and $f_{\pi}$ are the spin densities in the $5 p_{\sigma}$ and $5 \mathrm{p}_{\pi}$ orbitals respectively.

\section{References}

/1/ Mc Pherson, G.L., Sindel, L.J., Quarls, H.F., Frederick, C.B. and Doumit, C.J., Inorg. Chem. 14 (1975) 1831 .

/2/ Seifert, H.J. and Kischka, K.H., Thermochim. Acta, in press.

13/ Sanchez, J.P., Djermouni, B., Friedt, J.M. and Shenoy, G.K., Hyperfine Interactions 1 (1976) 313; Friedt, J.M. Sanchez, J.P., and Shenoy,G.K., J. Chem. Phys. 65 (1976) 5093. 